\title{
From transnational research collaboration to regional standards
}

\author{
Baldissera Giovani ${ }^{(1)}$, Gilles Cellier ${ }^{(2)}$, Madeleine McMullen ${ }^{(1)}$, Maria Saponari ${ }^{(3)}$, \\ Emilio Stefani ${ }^{(4)}$, Françoise Petter ${ }^{(1)}$
}

\author{
(1) European and Mediterranean Plant Protection Organization. 21, bd Richard Lenoir. FR-75011 Paris (France). E-mail: \\ bgiovani@euphresco.net \\ (2) ANSES. National Plant Health Laboratory. Tropical Pests and Diseases Unit. 7, chemin de L'IRAT. FR-97410 Saint- \\ Pierre, Reunion Island (France). \\ (3) Istituto per la Protezione delle Piante. Consiglio Nazionale delle Ricerche. Via Giovanni Amendola, 122. I-70126 Bari \\ (Italy). \\ (4) Università degli Studi di Modena e Reggio Emilia. Viale A. Allegri, 9. I-42121 Reggio Emilia (Italy).
}

Received 4 June 2018, accepted 21 December 2018, available online 16 January 2019.

This article is distributed under the terms and conditions of the CC-BY License (http://creativecommons.org/licenses/by/4.0)

Reliable and rapid diagnostic methods are essential to support inspection activities conducted by National Plant Protection Organizations (NPPOs) in the framework of their official mandate, and to evaluate the efficacy of control measures taken. Since 1998 the European and Mediterranean Plant Protection Organization (EPPO) has been supporting the harmonization of diagnostic methods for regulated pests in the EPPO region through the development of technical standards. In order to increase active collaboration among the organizations involved in plant health research activities at the national and regional levels, Euphresco (European Phytosanitary Research Coordination) was established in 2006 and funded by the EU as an ERANET project. Euphresco has subsequently evolved into a self-sustaining international network hosted by EPPO. This paper describes the EPPO diagnostic programme. It will also provide some examples of research projects funded through Euphresco that have provided valuable support for the development of pest-specific diagnostic protocols and will show how NPPOs can shape the research agenda of research funders and help to identify gaps to be addressed through transnational collaboration.

Keywords. Diagnostics, EPPO, Euphresco, Xylella fastidiosa, Acidovorax citrulli, 'Candidatus Liberibacter asiaticus', 'Candidatus Liberibacter americanus', 'Candidatus Liberibacter africanus'

\section{De la recherche collaborative internationale aux normes régionales}

Des méthodes de diagnostic fiables et rapides sont essentielles pour soutenir les activités d'inspection menées par les organisations nationales de la protection des végétaux (ONPV) dans le cadre de leur mandat officiel et pour évaluer l'efficacité des mesures prises. Depuis 1998, l'Organisation Européenne et Méditerranéenne pour la Protection des Plantes (OEPP) soutient l'harmonisation des méthodes de diagnostic des organismes nuisibles réglementés dans la région de l'OEPP et développe des normes. Afin de renforcer la collaboration nationale et régionale entre les organisations impliquées dans les activités de recherche en santé des végétaux, le réseau Euphresco (European phytosanitary research coordination) a été créé en 2006 et financé par l'UE en tant que projet ERA-NET. Euphresco a par la suite évolué pour devenir un réseau international autonome hébergé par l'OEPP. Cet article décrit le programme de diagnostic de l'OEPP. Il fournira également quelques exemples de projets de recherche financés par Euphresco qui ont apporté un soutien précieux à l'élaboration de protocoles diagnostiques et montrera également comment les ONPVs peuvent façonner le programme de recherche des bailleurs de fonds et contribuer à identifier les lacunes à combler par des collaborations transnationales.

Mots-clés. Diagnostique, OEPP, Euphresco, Xylella fastidiosa, Acidovorax citrulli, 'Candidatus Liberibacter asiaticus', 'Candidatus Liberibacter americanus', 'Candidatus Liberibacter africanus'. 


\section{INTRODUCTION}

The Mediterranean basin has been identified as one of the 25 biodiversity hotspots (Myers et al., 2000) in the world characterized by an exceptional concentration of endemic species and facing alarming habitat loss. Agriculture plays an important role in the economy of the region as it represents an important share of the labor force (The World Bank, 2018): moreover, the region has played an important role in the international trade (import and export) of plants and plant products. This makes the Mediterranean area particularly susceptible to the threats associated with plant pests and climate change (Giorgi \& Lionello, 2008). Countries, and particularly National Plant Protection Organizations (NPPOs), have to address these challenges in a context of reduced national resources and fragmentation of the European research area that has limited their communication and collaboration on common priorities.

\section{A REGIONAL APPROACH TO PLANT HEALTH}

Since 1951, the European and Mediterranean Plant Protection Organization (EPPO) and more recently (since 2009) also the Near East Plant Protection Organization (NEPPO) have been helping Mediterranean countries to strengthen plant protection activities and promote international cooperation. The EPPO Convention describes EPPO's functions (article V), which are:

- development of principles of good practice in the application of phytosanitary measures and regional standards;

- promotion of the harmonization of phytosanitary and other official plant protection measures, simplification and unification of phytosanitary regulations and certificates;

- advising Member Governments on: administrative, legislative and technical measures necessary to prevent the introduction and spread of regulated pests, (e.g. measures for inspection and testing, certification, treatment, survey and eradication, pest risk analysis) and on the measures necessary to register or authorize plant protection products, and to control their marketing and use on their territories;

- to coordinate and stimulate international campaigns between Member Governments against pests;

- to disseminate information to and from Member Countries.

Since 2014, EPPO facilitates cooperation in research on (the control of) pests and in the exchange of relevant scientific information by hosting the
Secretariat of the Euphresco network. Initiated as an EU-funded ERA-NET project, the network now includes (as of September 2018) organizations from more than 50 countries in five continents.

\section{HARMONIZATION OF PLANT HEALTH DIAGNOSTICS}

Since 1998, EPPO has been supporting the harmonization of diagnostic methods for regulated pests in the EPPO region through the development of technical standards. Harmonization of detection and identification methods avoids disputes on test results, thus contributing to a more efficient international trade of plants and plant products (Thiermann, 1999). As of September 2018, 131 diagnostic protocols have been approved by the NPPOs of the EPPO Member Countries, developed by Panels of experts nominated by Member Countries. EPPO diagnostic standards are of two types: horizontal and pest-specific. Horizontal standards include guidelines related to quality assurance issues, on how to perform specific methods (such as ELISA test for viruses, DNA barcoding as an identification tool for regulated pests, etc.). Pest-specific diagnostic protocols are related to (a) specific pest(s) and provide the guidance necessary for an expert or a member of competent staff who is specifically trained to detect and positively identify (a) pest(s) by a single test or combination of tests. Pest-specific diagnostic protocols usually include more than one method to take into account the capabilities of laboratories and the circumstances of use of the tests (such as testing in the framework of surveillance in an area where a pest is present, detection in imported consignments). For many years, the approach to diagnostic protocols has mostly been to include those tests that were already performed successfully in different laboratories in the EPPO region and more recently to give preference to those which had validation data available (Giovani et al., 2017). The EPPO Panel experts also ensure regular review of protocols (covering for example changes in the taxonomy of the pest or the availability of new tests) to identify which protocols need to be revised, based on the most recent scientific literature. The experts in the Panels also contribute to the identification of regulated or (re)emerging pests for which diagnostic protocols should be developed, upon approval by the EPPO Working Party on Phytosanitary Regulations. Having a tool (Euphresco) for research coordination and collaboration in-house, allows research projects to be undertaken that produce evidence for the development of EPPO standards and more generally support the daily activities of NPPOs. Transnational collaboration through Euphresco has contributed to maintain classic diagnostic capability, i.e. taxonomy, and has accelerated 
the development of expertise in new disciplines such as molecular biology. Prior to Euphresco, collaboration of diagnostic laboratories from different countries was limited to the research activities funded under EU programmes. These collaborations delivered important results such as diagnostic protocols evaluated through an interlaboratory comparison across a number of countries and validated. But EU R\&D programmes are able to only tackle a small number of problems and are not usually able to respond rapidly to changing needs and emergencies. Euphresco has allowed to secure annual funding for phytosanitary research activities through rapid and flexible procedures to deliver scientific evidence for the development of EPPO standards, to support the daily activities of national plant protection organizations and to strengthen phytosanitary policy at least.

\section{CASE STUDIES}

Since 2008, more than 80 research projects have been funded through Euphresco, focusing on different aspects of plant health such as preparedness, monitoring and surveillance, diagnostics, management and capacity building. As reliable and rapid diagnostic processes are essential for early detection and correct identification and ultimately contribute to successful pest management, many research projects have a diagnostic objective: development/optimization of tests, organization of interlaboratory comparisons i.e. test performance studies (TPS) or proficiency tests (PT), identification and exchange of reference material or development of best practices to maintain collections.

\subsection{Xylella fastidiosa}

The first report (2013) of Xylella fastidiosa on olive trees (Olea europaea) in Southern Italy alerted the whole EPPO region, as the bacterium is a regulated pest known to infect more than 300 plant species (EFSA, 2015), including economically important species for Mediterranean countries such as citrus (Citrus), grapevine (Vitis vinifera), stone fruits (Prunus) and olive (Olea europaea). The EPPO diagnostic protocol on Xylella fastidiosa PM 7/24 available at the time was outdated, both because it focused on the detection of the bacterium on grapevine and citrus (the main known host species for the American continent) and because of the tests recommended. An Expert Working Group was convened and work coordinated by the EPPO Secretariat. The Euphresco research project "Harmonized protocol for monitoring and detection of Xylella fastidiosa in its host plants and its vectors" (PROMODE) was initiated (2016) to enhance scientific knowledge to support the development of harmonized sampling and diagnostic procedures, for effective identification of Xylella fastidiosa in its host plants and vectors. Twenty-two laboratories from various EPPO member countries and a laboratory from the United States have been working on different activities, some of which are listed below:

- a PT was organized jointly with the EU-funded projects POnTE and Xf-ACTORS. Thirty-five laboratories from 18 countries participated in the PT coordinated by Italy. Proficiency was evaluated on the tests included in the revised PM 7/24: 4 DNA extraction methods (CTAB, Mericon Food Kit from Qiagen, Quick pick plant kit from Bionobile and DNeasy plant minikit from Qiagen), two PCR tests (the conventional PCR of Minsavage et al., 1994 and the real-time PCR of Harper et al., 2010 erratum 2013) and two ELISA tests (with Loewe and Agritest antibodies). The PT showed that different laboratories were proficient for different tests, and that different DNA extraction methods could be used with comparable results.

- A TPS was organized to produce validation data for different real-time PCR tests: Harper et al. (2010 erratum 2013), Li et al. (2013) (using standard TaqMan probe), Li et al. (2013) (using MGB-TaqMan probe) and Francis et al. (2006) (modified using Sybr green). The validation data have been included in the revised diagnostic protocol. The results of the TPS indicated that although all real-time PCR tests evaluated successfully detected the bacterium in the artificially contaminated samples, the highest performance values were obtained using the test designed by Harper et al. (2010 erratum 2013).

- A TPS was organized (POnTE and Euphresco projects) to evaluate, using insect material (Philaenus spumarius), DNA extraction methods (CTAB, Quick pick plant kit from Bionobile or extraction without grinding) and the following tests: real-time PCR from Harper et al. (2010), real-time PCR from Harper et al. (2010) in duplex with primers from Ioos et al. (2009), real-time PCR from Francis et al. (2006) (Sybr green and TaqMan), LAMP from Harper et al. (2010), modified by Yaseen et al. (2015). Twenty laboratories from 14 countries participated in the TPS, coordinated by France. The validation data have been included in the revised diagnostic protocol.

- Digital PCR is being assessed as a test for the absolute quantification and early detection of $X$. fastidiosa in host plants and vectors; high-throughput sequencing (also called Next Generation Sequencing, NGS) is also being assessed as an alternative to multilocus sequence typing (MLST) for subspecies determination; a triplex real-time PCR is also being developed. When results are available, they will be considered for inclusion in the future revision of the EPPO protocol. 
Under natural conditions, $X$. fastidiosa is transmitted by xylem sap-feeding insects. While the vectors of the disease are relatively well known in North and South America, knowledge in the European context is limited. The Euphresco project "Xylella fastidiosa and its insect vectors" (2016-F-221) was recently initiated (2018). The consortium gathers 14 laboratories to improve the knowledge on European vectors, and in particular: survey potential vector species associated with $X$. fastidiosa hosts, evaluate sampling methods for vector species in the environment, improve detection of $X$. fastidiosa in potential vectors (validation of the non-destructive extraction methods, development of real-time PCR tests) and cultural and chemical control methods related to vector lifecycle. In the next months, the project will produce useful information to further improve the EPPO diagnostic protocol on $X$. fastidiosa and to support the development of a new protocol on Philaenus spumarius, Philaenus italosignus and Neophilaenus campestris.

\subsection{Acidovorax citrulli}

Acidovorax citrulli is the causal agent of bacterial fruit blotch of cucurbit plants, primarily watermelon (Citrullus lanatus) and melon (Cucumis melo). Given the potential for the bacteria to spread via the distribution of contaminated commercial seeds (A. citrulli is a seed-borne and seed-transmitted pathogen), in 2014 it was added to the EPPO A1 List (pests that are absent from the EPPO region and recommended for regulation as quarantine pests). A few outbreaks have been occurring in the EPPO region. The current version of the EPPO diagnostic protocol PM 7/127(1) on this pest was developed in the framework of the EU-funded project TESTA, with contributions from Italian and Dutch experts and was reviewed by the EPPO Panel on Diagnostics in Bacteriology. In addition, the Euphresco project "Consensus detection and identification protocol for Acidovorax citrulli on cucurbit seeds" (DIP-ACIT) was initiated in 2016 to provide validated methods, protocols and procedures for the detection of A. citrulli in seed lots of melon and watermelon. The laboratories involved in the detection and identification of $A$. citrulli face two main challenges:

- the bacterium is slow-growing, therefore, a suitable medium had to be developed and validated;

- isolation from seeds is not possible, due to inhibitors and saprophytes.

Therefore, diagnostic laboratories should rely on molecular detection using a validated real-time PCR test, to be performed following a nucleic acid extraction from seed (Giovanardi et al., 2018). A TPS involving 10 laboratories was organized in the framework of the project and coordinated by Italy, in order to produce validation data for some of the tests recommended in the EPPO diagnostic protocol as well as a new test. The tests evaluated were:

- semi-selective agar medium for bacterial isolation;

- PCR tests from Schaad et al. (2000) and Zivanovic

$\&$ Walcott (2017) for A citrulli identification and grouping;

- the real-time PCR test according to Woudt et al. (2009a, 2009b) on seed extracts;

- pathogenicity test on melon and watermelon.

Research activities have also been undertaken to validate the use of Matrix-Assisted Laser Desorption/ Ionisation Mass Spectrometry (MALDI MS) for the identification of $A$. citrulli. The findings will be instrumental to the inclusion of the test in future protocol revisions and provide useful data on the use of MALDI MS for diagnostic purposes.

\section{3. 'Candidatus Liberibacter asiaticus' and 'Candidatus Liberibacter africanus'}

'Candidatus Liberibacter asiaticus' and 'Candidatus Liberibacter africanus' are associated to Huanglongbing (HLB/Citrus greening), one of the most destructive diseases of citrus in Asia, Africa, and America, but not yet detected in the EPPO region. The presence of one of its vectors (Trioza erytreae) in the Iberian Peninsula since 2014 (Pérez-Otero et al., 2015) which is spreading (Arenas-Arenas et al., 2018) poses a threat to the European citrus industry. As part of an initial diagnosis (see EPPO diagnostic protocol PM 7/121[1]), the visual inspection of symptomatic plants is a routine method for the surveillance of HLB disease, but symptoms alone are not enough to complete a diagnosis, as they can be confused with nutritional disorders (zinc, iron, manganese deficiencies) or with other diseases (Citrus tristeza virus, stubborn disease of citrus, citrus blight, Australian citrus dieback). Conventional PCR is a sensitive and specific method, but it can lead to false negative results due to the low titre and uneven distribution of the bacterium in the host plant, especially at the early stage of the infection (Jagoueix et al., 1994). Various real-time PCR tests had been published and assessed for their performance, but this was done using different procedures. The Euphresco project "Comparison of multiples real-time PCR and real-time LAMP detection methods for the plant pathogen 'Candidatus Liberibacter' spp. causing the Huanglongbing disease on Citrus spp." (HLBVALID) was initiated (2016) with the main objective to produce validation data through a comparable assessment of the main diagnostic tests (FAO, 2006; EPPO, 2014; FAO, 2016) to guarantee the reliability of the results obtained (submission in progress). Laboratories from six countries participated in a TPS coordinated by 
France to compare the performance of three real-time PCR tests from Li et al. (2006), Morgan et al. (2012) and Bertolini et al. (2014). The analytical specificity, analytical sensitivity, and repeatability (EPPO, 2014) on different samples from a DNA collection of 17 target and 14 non-target were evaluated. The samples originated from various countries (France - including Guadeloupe and Reunion Island, India, Japan, Portugal, South Africa, Spain, Turkey, Uganda, and United States of America) were extracted from various Rutaceae cultivars. Also, two samples from HLB-free but diseased plants were collected from:

- potato infected with 'Ca. L. solanacearum' (CLso), a species genetically close to the HLB disease causing strains;

- citrus trees infected with Xanthomonas citri pv. citri (Xcc), a citrus pathogen causing citrus canker.

The performance data of the real-time PCR was compared to that of the conventional duplex PCR targeting the $\beta$-operon (Hocquellet et al., 1999; Teixeira et al., 2005) in the same laboratory conditions on the same panel and considered as the reference method (EPPO, 2014).

A second test performance study was organized in Autumn 2018 and involved 10 international laboratories to validate the inter-laboratory robustness of the tests.

\section{CONCLUSIONS}

International collaboration brings benefits to various plant health players and stakeholders. While collaboration of research organizations strengthens capacity building, favors multidisciplinary approaches and contributes to higher quality outputs that have a regional value compared to national activities alone, collaboration of regulators builds mutual trust and confidence and contributes to wider adoption of standards.

By bringing together regulators, national and regional phytosanitary research programme owners and managers, official laboratories, academia and private companies and other plant health stakeholders, Euphresco and EPPO address common regional and international plant health challenges in a finely orchestrated dialogue where policy shapes research while research serves policy.

\section{Bibliography}

Arenas-Arenas F.J., Duran-Vila N., Quinto J. \& Hervalejo Á., 2018. Is the presence of Trioza erytreae, vector of huanglongbing disease, endangering the Mediterranean citrus industry? Survey of its population density and geographical spread over the last years. J. Plant Pathol., 100(3), doi: 10.1007/s42161-018-0109-8

Bertolini E. et al., 2014. Tissue-print and squash real-time Polymerase Chain Reaction for direct detection of 'Candidatus Liberibacter' spp. in citrus plants and insect vectors. Plant Pathol., 65,1142-1158.

EFSA, 2015. Scientific opinion on the risks to plant health posed by Xylella fastidiosa in the EU territory, with the identification and evaluation of risk reduction options. EFSA J., 13(1), 3989.

EPPO PM 7/98 (1), 2014. Specific requirements for laboratories preparing accreditation for plant pest diagnostic activity. EPPO Bull., 44(2), 117-147.

EPPO PM 7/121 (1), 2014. 'Candidatus Liberibacter africanus', 'Candidatus Liberibacter americanus' and 'Candidatus Liberibacter asiaticus'. EPPO Bull., 44(3), 376-389.

FAO, 2006. Diagnostic protocols for regulated pests (ISPM 27). In: International standard for phytosanitary measures 27. Roma: International Plant Protection Convention (IPPC).

FAO, 2016. Draft annex to ISPM 27: 'Candidatus Liberibacter' spp. on Citrus spp. (2004-2010). In: International standard for phytosanitary measures 27. Roma: International Plant Protection Convention (IPPC).

Francis M. et al., 2006. Genome-based PCR primers for specific and sensitive detection and quantification of Xylella fastidiosa. Eur. J. Plant Pathol., 115, 203-213.

Giorgi F. \& Lionello P., 2008. Climate change projections for the Mediterranean region. Global Planet. Change, 63(1-2), 90-104.

Giovanardi D., Sutton S.A., Stefani E. \& Walcott R.R., 2018. Factors influencing the detection of Acidovorax citrulli in naturally contaminated cucurbitaceous seeds by PCR-based assays. Seed Sci. Technol., 46(1), 93-106.

Giovani B. et al., 2017. EPPO and Euphresco: how to ensure high quality, harmonised plant health diagnostics in the EPPO region. Euroreference, 3, 37-41.

Harper S.J., Ward L.I. \& Clover G.R.G., 2010. Development of LAMP and real-time PCR methods for the rapid detection of Xylella fastidiosa for quarantine and field applications. Phytopathology, 100, 1282-1288.

Hocquellet A., Toorawa P., Bove J.M. \& Garnier M., 1999. Detection and identification of the two Candidatus Liberibacter species associated with citrus huanglongbing by PCR amplification of ribosomal protein genes of the beta operon. Mol. Cell. Probes, 13(5), 373-379.

Ioos R., Fourrier C., Iancu G. \& Gordon T.R., 2009. Sensitive detection of Fusarium circinatum in pine seed by combining an enrichment procedure with a real-time polymerase chain reaction using dual-labelled probe chemistry. Phytopathology, 99, 582-590.

Jagoueix S., Bove J.M. \& Garnier M., 1994. The phloemlimited bacterium of greening disease of citrus is a member of the alpha subdivision of the Proteobacteria. Int. J. Syst. Bacteriol., 44, 379-386. 
Keremane M.L. et al., 2015. A rapid field detection system for citrus huanglongbing associated 'Candidatus Liberibacter asiaticus' from the psyllid vector, Diaphorina citri Kuwayama and its implications in disease management. Crop Prot., 68, 41-48.

Li W., Hartung J.S. \& Levy L., 2006. Quantitative real-time PCR for detection and identification of 'Candidatus Liberibacter' species associated with citrus huanglongbing. J. Microbiol. Methods, 66, 104-115.

Li W. et al., 2013. Development and systematic validation of qPCR assays for rapid and reliable differentiation of Xylella fastidiosa strains causing citrus variegated chlorosis. J. Microbiol. Methods, 92, 79-89.

Minsavage G.V. et al., 1994. Development of a polymerase chain reaction protocol for detection of Xylella fastidiosa in plant tissue. Phytopathology, 84, 456-461.

Morgan J.K. et al., 2012. Improved real-time PCR detection of 'Candidatus Liberibacter asiaticus' from citrus and psyllid hosts by targeting the intragenic tandem-repeats of its prophage genes. Mol. Cell. Probes, 26, 90-98.

Myers N. et al., 2000. Biodiversity hotspots for conservation priorities. Nature, 403(6772), 853-858

Pérez-Otero R., Mansilla J.P. \& del Estal P., 2015. Detección de la psila Africana de los cítricos, Trioza erytreae (Del Guercio, 1918) (Hemiptera: Psylloidea: Triozidae), en la Península Ibérica. Arquivos Entomolóxicos Galegos, 13, 119-122.

Schaad N.W., Song W.Y. \& Hatziloukas E., 2000. PCR primers for detection of plant pathogenic species and subspecies of Acidovorax. US Patent 6146834A, 200011-14.
Teixeira D.C. et al., 2005. 'Candidatus Liberibacter americanus', associated with citrus huanglongbing (greening disease) in Sao Paulo State, Brazil. Int. J. Syst. Evol. Microbiol., 55, 1857-1862.

The World Bank, 2018. World development indicators (2018), https://datacatalog.worldbank.org/dataset/ world-development-indicators, (2018-09-18).

Thiermann A.B., 1999. The sanitary and phytosanitary agreement of the World Trade Organisation. In: Meester G., Woittiez R.D. \& De Zeeuw A., eds. Plants and politics. Wageningen, The Netherlands: Wageningen Press, 137-145.

Woudt B., Beerepoot A.J. \& Carter L.L., 2009a. A new PCR method for detection of Acidovorax citrulli on seed. Poster. St. Paul, MN, USA: The American Phytopathological Society.

Woudt B., Koenraadt H.M.S., Oosterhof J. \& van Betteray B., 2009b. Development of specific primers for the molecular detection of Acidovorax avenae subsp. citrulli. In: Proceedings of the EPPO Conference on diagnostics, 2009-05-10/15, York, Great Britain.

Yaseen T. et al., 2015. On-site detection of Xylella fastidiosa in host plants and in "spy insects" using the real-time loop-mediated isothermal amplification method. Phytopathol. Mediterr., 54, 488-496.

Zivanovic M. \& Walcott R.R., 2017. Further characterization of genetically distinct groups of Acidovorax citrulli strains. Phytopathology, 107(1), 29-35.

(30 ref.) 